\title{
Significance of Literature in Foreign Language Teaching
}

\author{
Ruzbeh Babaee ${ }^{1} \&$ Wan Roselezam Bt Wan Yahya ${ }^{1}$ \\ ${ }^{1}$ Faculty of Modern Languages and Communication, University Putra Malaysia, Malaysia \\ Correspondence: Ruzbeh Babaee, Faculty of Modern Languages and Communication, University Putra Malaysia, \\ Malaysia. E-mail: rbabaei30@yahoo.ca
}

Received: January 23, 2014 Accepted: March 5, 2014 Online Published: March 26, 2014

doi:10.5539/ies.v7n4p80

URL: http://dx.doi.org/10.5539/ies.v7n4p80

\begin{abstract}
This research aims to consider literature as a significant tool for teaching fundamental language skills including speaking, listening, reading and writing. Reasons for the use of literature in language classrooms and major factors for choosing appropriate kinds of literary texts in such classes should be highlighted in order to make readers aware of the primary reasons that why language instructors are suggested to use literary texts. Furthermore, teaching language skills through literature, advantages of various kinds of genres of literature to language teaching and some issues faced by language instructors in teaching language via literature are considered in the present study.
\end{abstract}

Keywords: literature, language skills, foreign language teaching, target language

\section{Introduction}

The theories of language teaching and the trends in language acquisition have changed over the last hundred years, influenced by linguistic, psychological, educational and political perspectives derived from "a mixture of assertion, theory, observation and experiment" (Hall \& Cook, 2012, p. 272). But, since two decades ago, literature has been considered as an influential tool and trend in foreign language teaching. Literature plays a significant role in language curriculum and teaching. However, many language instructors have argued that why and how literature should be embodied in language curriculum. Many instructors have considered the use of literature in language teaching as a valuable and interesting strategy (Sage, 1987). Although Literature is very significant in the language curriculum, many language instructors have faced with some problems in their teaching language through literature. First, there are few suitable pedagogical materials used for teaching language through literature. Second, there is not enough preparation in the field of literature for teaching in the language curriculum. Third, there are not enough goals to define the significance of literature in language classrooms. A couple of language teachers have attempted to consider literature in their teaching, but insufficient training in this area has made them unable to fully achieve their goals.

The language instructors are undeniably a crucial factor in language education for learners (Pinter, 2006). They also play a significant role in teaching language through literature. Thus, in order to make their teaching efficient they require considering some factors. First, they should define the goal of teaching language based on the learners' expectations and demands. Second, they should choose the suitable language teaching approach. Third, they should choose literary texts relevant to the goals of their teaching. By considering these goals, they can have affective teaching language through literature.

The present study investigates why language instructors should use literature for language teaching and what kind of literature should be used in language classes. In addition, the advantages of using literature for teaching language are considered. Totally, the position of literature as a significant instrument for teaching a foreign language will be examined in the present study.

\section{Literature Review}

There is a close and undeniable relationship between literature and language. Literature is composed of language and it also provides space for the applications of language. Brumfit and Carter (1986) considered literature as "an ally of language" (1). Such method is undoubtedly novel, because literature has been greatly employed as a means in teaching language skills. Here, first, we consider the changing function of literature in the tradition of foreign language teaching and then come to its current condition within the communicative method. Literature, in the grammar translation method, played a role. Literature of the target language was read, translated, and used 
as samples of good writing and "illustrations of the grammatical rules" (Duff \& Maley 1990, p. 3). This teaching approach considered form, and learning based on grammatical rules and the lexical items in the text. In this approach, there was no literary interest and literary texts were just used as samples of grammatical structures and good writings. After disusing this approach, literary texts also became forgotten for foreign language instructors.

For the structural methods to teaching language, literature was disgraced as an instrument, since it presented the old fashion. The functional-notional approached did not consider literature, since in this approach the significance is on communication and they represent genuine language samples. Literature was not seen as a communicative tool or a genuine example of language application.

However, since two decades ago, the interest in literature as a valuable tool in language teaching has been raised (Duff \& Maley, 1990, p. 3). It is in line with the new communicative approaches that have found in reading literature their desired principles namely communicative competence that asks foreign language learners to communicate in the foreign language and to consider authentic communicative conditions (Sanz \& Fernández, 1997).

Certainly, literature paves the way for language teaching through a communicative approach. A couple of writers such as Brumfit and Carter (1986) and Lazar (1993) have rejected the notion of the existence of a particular literary language and stated that the language used in literature is an ordinary language including linguistic traits such as metaphors, similes, poetic lexis, etc.. These features cannot be seen as literature specifics because they also appear in common language application. But, in literature these features have other implications.

Teaching language through literature gives student motivation for learning. As Scott (2004) states "When I teach my advanced French grammar course, students engage in a semi-traditional, systematic study of grammar, and are also required to read a novel. The novel is selected for its relevance to students' experiences in order to engage them in extensive reading for pleasure" (p. 278). Scott observes that learners use grammar actively through reading literature. Furthermore, Mason (2004) observes that literature is more pleasant and interesting than traditional methods of instruction, and learners can obtain other aspects of language from literary works.

The present study considers the benefits of reading literature both as a common language and a literary language in foreign language learning.

\section{Reasons for Teaching Literature}

Using literature for teaching four language skills including writing, reading, speaking, and listening as well as language components such as grammar, vocabulary and pronunciation seems to have become very popular in the area of teaching and learning a foreign language since two decades ago. Furthermore, in translation classes, sometimes language instructors ask students to translate some kinds of literature into their mother language because translation makes students able to practice their pragmatic, syntactic, stylistic and semantic knowledge. In the following, it is considered that why language instructors use literature in teaching language and what are the major criteria for selecting appropriate literary texts for teaching a language?

Hadaway et al. (2002) suggest three benefits of using literature for teaching language. The first advantage considers the contextualization of language. Students get familiar with the application of language in various conditions when they read a literary work. The second benefit considers social factors which are embedded in different genres of literature. The third advantage considers the natural and meaningful application of language which are accomplished via illustrations and use of descriptive language in literature.

According to Obediat (1997), literature can help learners obtain a competence in target language, learn the usage of idiomatic expressions, speak accurately, and become more fluent and creative in the target language. Also, as Custodio and Sutton (1998) observe, literature opens doors of opportunity and permits learners to ask, criticize, and investigate. Briefly, literature represents the learners a rich resource of authentic material. If the learners achieve this material, then they will be able to internalize the language at a high level (Elliot, 1990).

\subsection{Using Literature in Language Classrooms}

Collie and Slater (1990) observe that four major factors convince a language instructor to decide to use literary texts for teaching language. These factors are genuine material, cultural enhancement, language enhancement and personal participation. Moreover, universality, non-triviality, variety, interest, and creativity are some other factors for using literature in language teaching.

In addition, Duff and Maley (1990) argue that literature is used for three reasons as a means of second language teaching (6). First of all is the linguistic reason demonstrating that literature is influential in language teaching since it provides the students with real samples of language applications. It is of great significance for foreign 
language learners to be taught in different genres and styles and to be able to distinguish the function of each of them.

The second reason is methodological and considers the idea that literary texts can have different interpretations, thus they produce different ideas among the learners and this leads to creative, motivated interactions with the text, the learners and the teacher (Widdowson, 1983).

The third reason is that the motivational factors are of great significance since the literary texts represent the authentic feelings of their authors and this produces a strong motivation in the learners. By the help of the literary texts, the students can have access to this individual experience and are able to relate what they read to the real world. Literature has the capacity to create authentic conditions for the learners to practice and learn a foreign language with motivation.

\subsection{Factors for Choosing Appropriate Works of Literature in Training a Foreign Language}

Factors such as culture, interest, motivation and language level of the students should be considered when a language instructor wants to select a literary text for a foreign language classroom. Reading literary texts has valuable effects on the learner's linguistic knowledge when it is interesting and meaningful. Selecting texts about the real-life experiences, desires and emotions of the learners is also significant. Furthermore, language difficulty should be regarded. Simple language of a literary work can facilitate the understanding of the literary text but it cannot be seen as the most crucial factor. Criteria such as appeal, interest, and relevance are of more significance. Other factors like enjoyment, pleasure and fun all help learners treat the linguistic problems that sometimes are serious in less interesting materials (Collie \& Slater, 1990).

\section{Literary Work and Teaching Language}

Literature is of great significance in teaching speaking, listening, reading and writing skills. While it is typical to teach every language skill separately, it should be considered that when using literature for teaching language, the four skills (speaking, listening, reading, and writing) should not be taught separately. Instead, they should be taught in an integrated manner. Instructors should consider the four skills as an essential segment of oral as well as written language application.

\subsection{Literary Work and Reading}

Language instructors should choose a student-based and dynamic method towards understanding of literary texts. In reading classes, discussions can begin literally by asking questions about setting, characters, and plot of selected texts. When learners have literal understanding, then they can go to the inferential level in which they should have some investigations and interpretations of the characters, settings, and themes as well as the author's view point. After understanding a literary text both literally and inferentially, learners should be ready for a group work in which they can share their assessments of the work. The individual evaluation motivates the learners to activate their imagination about the work and even find some solutions to their problems.

\subsection{Literary Work and Writing}

Literature is a valuable and reliable source for developing writing skills in foreign language classes. Literature provides the learners with a model that provokes them to write like the original work in content, theme, style and organization. Also, literature embodies variety of themes to write on. Thus, it can give enough ideas to the learners to start their writing with.

\subsection{Literary Work, Speaking, and Listening}

Literature can be a valuable source for teaching speaking and listening skills. Activities such as oral reading, dramatization, pantomiming, discussion, and group activities can be considered as the ways through which language teachers can improve the students' listening and speaking.

\section{Advantages of Teaching Different Genres of Literature}

\subsection{Use of Poetry in Teaching Language}

Poetry is a significant genre for teaching and learning language skills. Some benefits of teaching poetry for language learning can be counted as follows:

(1) Providing learners with different viewpoints towards language applications.

(2) Motivating the learners for personal interpretations and explanations.

(3) Evoking emotions and ideas in both heart and mind.

(4) Making the learner familiar with figures of speech (metaphor, simile, etc.). 
According to Çubukçu (2001), poetry is an encouraging and interesting exercise with the elements of rhythm conveying "love and appreciation for the sound and power of language." (1) Thus, it can be noted that the learners become familiar with aspects such as stress, pitch, juncture, and intonation of the foreign language through reading poetry.

In addition, it should be noted that different types of poetry such as epic, lyric, ballad, sonnet, etc. can be used in foreign language teaching. Using different types of poetry helps learners become familiar with different kinds of language applications as well as different poetic styles.

\subsection{Use of Short Story in Teaching Language}

Short story can be seen as a significant genre for teaching language. In short stories, characters play authentically and symbolically, as individuals do in their daily life. Indeed, short stories mirror and illuminate human lives (Sage, 1987). Considering short story in foreign Language classes has advantages such as (Ariogul, 2001):

(1) Facilitating the learners' reading task because of being short and simple in comparison with other literary genres.

(2) Promoting the learners' attitudes and knowledge on different cultures.

(3) Offering a world of wonders and mystery.

(4) Developing critical thinking ability.

(5) Making the learners feel comfortable and free.

Briefly, the application of short fiction is very influential in foreign language classrooms. Also, short stories, like other genres of literature, develop the cognitive analytical ability (Sage, 1987).

\subsection{Use of Drama in Teaching Language}

Drama is an enrich source for teaching language. By using drama the learners can learn the application of language. Drama can raise the learners' awareness towards the target language and culture. The instructors can use drama to promote the learners' comprehension of life experience (Sariçoban, 2004). The advantages of teaching drama, as Lenore (1993) observes, are as follows:

(1) Stimulating the imagination and promoting creative thinking.

(2) Developing critical thinking ability.

(3) Heightening influential listening skills.

(4) Increasing the learners' empathy and awareness.

(5) Reinforcing positive self-concept.

(6) Providing the instructors with a fresh perspective on teaching.

(7) Developing creativity, originality, sensitivity, flexibility, cooperation, and communication skills.

(8) Helping the learners develop their level of competence with respect to their receptive and productive skills.

(9) Helping the learners develop new opinions and thoughts.

The use of drama can be a very influential way in communication-based language teaching. Authentically, drama helps the learners develop their understanding of the verbal as well as nonverbal features of the target language.

\subsection{Use of Novel in Teaching Language}

Novel can be a very rich source for developing linguistic structures as well as learning the target language. Choosing the appropriate novel can give the learner enough motivation to learn the target language. Using novel for learning a foreign language can have the following benefits:

(1) Developing the learners' knowledge about different cultures, traditions, societies, and people.

(2) Offering real life like settings.

(3) Giving the learners the chance to use their creativity.

(4) Improving critical thinking ability.

(5) Stimulating the learners' imagination.

(6) Developing both oral and written language skills.

When selecting a novel for teaching language, the instructor should consider whether the novel has an interesting 
story that motivates the entire class. Moreover, characters, themes, and settings of a novel should be considered in selecting a novel. Particular themes, ideas, motifs and concepts that are developed in language classes should also exist in the novel.

Totally, using an appropriate novel raises motivation and interest in learners. Although some learners may think reading a novel is studious and boring, it can be an influential tool for developing reading comprehension skills and building vocabulary. In fact, reading novel broadens the learners' horizons, and makes them aware of other cultures, and also develops their intercultural communication skills.

\section{Conclusion}

Literature provides opportunities for foreign language classes and can appeal to the students with various learning styles. Literary texts are reliable sources of linguistic inputs and can help the students practice the four skills-speaking, listening, reading and writing. In this study, we demonstrated the benefits of using literature in foreign language teaching. Literature can help the students enhance their perception of other cultures and societies. Also, literary texts can consider authentic subjects like love and war that one may experience in the real world. Indeed, literature is representational instead of referential. While referential language tends to communicate at only one level and is informational, representational language of literature considers the students and involves their feelings and perceptions of the real world. Literary texts help the students to activate their imagination and develop their emotions.

\section{References}

Ariogul, S. (2001). The Teaching of Reading through Short Stories in Advanced Classes (Unpublished M.A Thesis). Hacettepe University, Ankara.

Brumfit, C. J., \& Ronald, A. C. (Eds.). (1986). Literature and Language Teaching. Oxford: Oxford University Press.

Collie, J., \& Slater, S. (1990). Literature in the Language Classroom: A Resource Book of Ideas and Activities. Cambridge: CUP.

Çubukçu, F. (2001). Use of Poetry for EFL Purposes (Unpublished article). Dokuz Eylül University, Izmir.

Custodio, B., \& Sutton, M. (1998). Literature-Based ESL for Secondary School Students. TESOL Journal, 7(5), $19-23$.

Duff, A., \& Maley, A. (1990). Literature. Oxford: Oxford University Press.

Elliot, R. (1990). Encouraging reader-response to literature in ESL situations. ELT Journal, 4(3), 191-198. http://dx.doi.org/10.1093/elt/44.3.191

Hadaway, N. L., Vardell, S. M., \& Young, T. A. (2002). Literature-based instruction with English language learners, $\mathrm{K}-12$. Boston: Allyn and Bacon.

Hall, G., \& Cook, G. (2012). Own language use in language teaching and learning. Language Teaching, 45, 271-308.

Lazar, G. (1993). Literature and Language Teaching. Cambridge: Cambridge University Press. http://dx.doi.org/10.1017/CBO9780511733048

Lenore, K. L. (1993). The Creative Classroom: A Guide for Using Creative Drama in Classroom. U.S.A: Elsevier Inc.

Mason, B., \& Krashen, S. (2004). Is Form-Focused Vocabulary Instruction Worth While? RELC Journal, 35(2), 179-185. http://dx.doi.org/10.1177/003368820403500206

Obediat, M. (1997). Language vs. Literature in English Departments in the Arab World. English Teaching Forum.

Pinter, A. (2006). Teaching young language learners. Oxford: Oxford University Press.

Sage, H. (1987). Incorporating Literature in ESL Instruction. New Jersey: Prentice-Hall Inc.

Sanz, M., \& Fernández, C. (1997). Principios Metodológicos de los Enfoques Comunicativos. Madrid: Fundación Antonio Nebrija.

Sariçoban, A. (2004). Using Drama in Teaching Turkish as a Foreign Language. Eurasian Journal of Educational Research, 14, 13-32.

Scott, V. M. (2004). Cloze Windows and Aesthetic Discoveries: Opening Visions for Teaching Literature. The 
French Review, 78(2), 278.

\section{Copyrights}

Copyright for this article is retained by the author(s), with first publication rights granted to the journal.

This is an open-access article distributed under the terms and conditions of the Creative Commons Attribution license (http://creativecommons.org/licenses/by/3.0/). 